Phair, J.P., Bondy, P.K. \& Abelson, D.B. (1965) Diabetes mellitus, Addison's disease and myxoedema. J. clin. Endocr. 25, 260.

Plattane, H.C. (1965) Diabète et maladie d'Addison. Rev. med. Suisse rom. 85, 613.

Selby, J.B. (1962) Addison's disease associated with diabetes mellitus. Amer. Practit. 13, 347.

Solomon, N., Carpenter, C.C.J., Bennett, I.L. \& Harvey, A.McG. (1965) Schmidt's syndrome and coexistent diabetes mellitus. Diabetes, 14, 300.
Thorn, G.W., Farsham, P.H., Prunty, F.T.G., Bergner, G.E. \& Hills, A.G. (1949) Clinical studies in Addison's disease. Ann. N.Y. Acad. Sci. 50, 646.

Tzagourins, M. \& HAMwI, G.J. (1967) The prevalence of diabetes mellitus in patients with Addison's disease. Metabolism, 16, 213.

Ungar, B., Stocks, A.E., Martin, F.I.R., Whittingham, S. \& MACKAY, I.R. (1967) Intrinsic factor antibody in diabetes mellitus. Lancet, ii, 77.

WeHRMACHER, W.H. (1961) Addison's disease with diabetes mellitus. Arch. intern. Med. 108, 114.

\title{
Lymphosarcoma during the course of myeloid leukaemia
}

\author{
J. J. TAYLOR \\ M.B., B.S., M.C.Path. \\ Consultant Haematologist, \\ United Birmingham Hospitals
}

THE co-existence of malignant lymphoma and chronic myeloid leukaemia has rarely been recorded. Because of the theoretical implications of such an association, the occurrence of lymphosarcoma in a woman with busulphantreated chronic myeloid leukaemia is here reported.

\section{Case report}

The patient, a 52-year-old housewife and shop assistant, presented in October 1964 with complaints of excessive tiredness recently, anorexia and weight loss. The latter may have occurred over a longer period of perhaps 9 months. The only abnormal clinical findings at that time were mild pyrexia $\left(99^{\circ} \mathrm{F}\right)$, an appendicectomy scar and a palpable spleen tip, approximately 1 in. below the costal margin.

Investigations. $\mathrm{Hb} 12.9 \mathrm{~g} / 100 \mathrm{ml}$, PCV $37 \%$, WBC $49,400 / \mathrm{mm}^{3} ; 70 \%$ of the white cells were polymorphonuclear neutrophils, $10 \%$ metamyelocytes $6 \%$ myelocytes and $2 \%$ 'blast' cells. By the time she was admitted to hospital, 3 months later, the spleen was palable 4 in. below the costal margin, $\mathrm{Hb}$ had fallen to $11.1 \mathrm{~g} / 100 \mathrm{ml}$ and total WBC had risen to $186,900 / \mathrm{mm}^{3}$ (69 neutrophils $11 \%$ metamyelocytes, $8 \%$ myelocytes and $3 \%$ promyelocytes). Platelet count was then $793,000 / \mathrm{mm}^{3}$. Radiography revealed no evidence of hilar lymphadenopathy.

Busulphan therapy was commenced in January 1965. The courses and doses of this drug, and periodic white cell and platelet counts are shown in Fig. 1 . Hb levels remained about $10 \mathrm{~g} / 100 \mathrm{ml}$

\author{
D. W. Evans \\ B.Sc., M.D., M.R.C.P., D.C.H. \\ Consultant Physician, \\ United Cambridge Hospitals
}

until the terminal phase of the illness in September 1966.

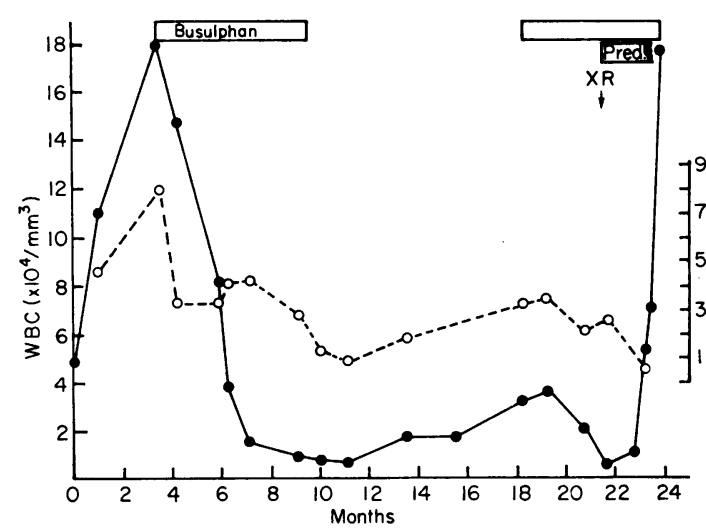

Fig. 1. Response of white cells and platelets to treatment over a 2-year period.

She began to feel well again March 1965 but was troubled by new symptoms of numbness and tingling in fingers and thumbs in July 1965. There was some blunting of pain sensation at the tips of these digits and sensory neuropathy was diagnosed. Serum $B_{12}$ was normal and there was no response to oral vitamin $B_{1}$. The paraesthesiae had disappeared by May 1966 and she remained well until June 1966 when she became aware of rapidly-enlarging tender lymph nodes on both sides of her neck. On examination there proved to be tender, mobile, rubbery nodes up 
to 1 in. in long diameter, in the cervical, axillary and inguinal regions. Her spleen was palpable, as before, about 4 in. below the costal margin. Radiography showed bilateral hilar lymphadenopathy.

Aspiration biopsy of the right cervical lymph nodes revealed appearances of lymphosarcoma (Fig 2). Surgical cervical node biopsy revealed

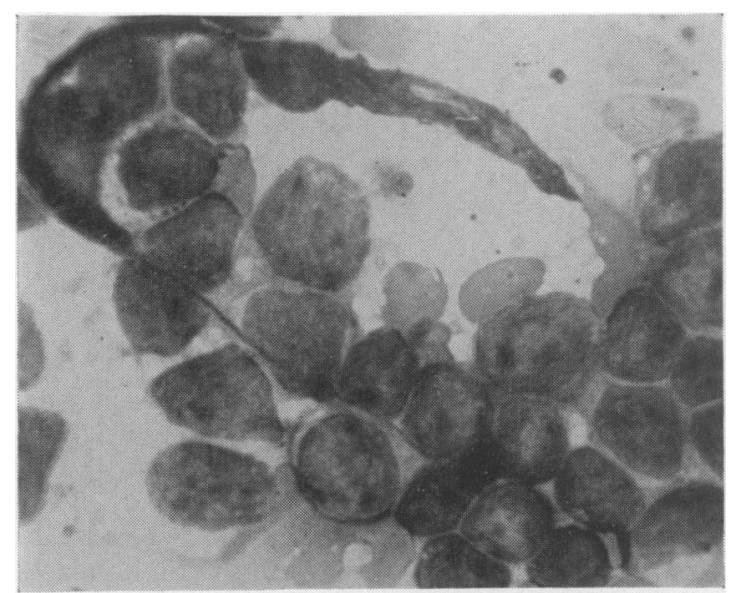

FIG. 2. Aspiration biopsy showing abnormal lymphoid cells seen in lymphosarcoma. Occasional granulated cells. (May-Grünwald-Geimsa, $\times$ 800).

destruction of the normal architecture and replacement by sheets of cells in which mitotic figures were numerous. The majority of these cells were lymphocytic in type but some large, more immature, cells resembling myelocytes were also present. There was some peroxidase activity in a small proportion of the immature cells but most seemed to be of the lymphoid or reticulum cell series. Appearances were consistent with the presence of lymphosarcoma in a patient with myeloid leukaemia (Fig. 3). Sternal biopsy showed hypercellular normoblastic marrow with conspicuous increase in megakaryocytes and myeloid preponderance chiefly due to myelocytes, though with some increase in promyelocytes and myeloblasts. The peripheral blood about this time contained 9200 white cells/ $\mathrm{mm}^{3}, 14 \%$ of which were primitive cells; the neutrophil alkaline phosphatase count was 5 compared with a control of 60 .

The cervical lymphadenopathy responded to a course of local $X$-ray therapy. Oral prednisone (20 mg daily) was started during this course and the dose reduced at an outpatient attendance in August 1966, when she was very well. However, terminal acute leukaemia (WBC up to $184,000 / \mathrm{mm}^{3}$ with $38 \%$ blast cells) developed towards the end of that month and did not respond to increased steroid dosage or 6mercaptopurine. She died in hospital on 19 September 1966.

Necropsy revealed haemorrhage into the right temporal lobe of the brain and bilateral basal bronchopneumonia. There was enlargement of cervical, axillary, inguinal, hilar and intraabdominal lymph nodes which had a fleshy appearance on section. The spleen weighed $1780 \mathrm{~g}$ and was the site of numerous infarcts.

\section{Discussion}

There are numerous reports in the literature of leukaemia complicating various types of reticulosis, the association between chronic lymphatic leukaemia and lymphosarcoma being particularly well recognized. Acute leukaemia may be the terminal stage of reticulum cell sarcoma (Beutler, 1954 ; Zeffren \& Ultmann, 1960), lymphosarcoma (Sternberg, 1916; Flashman \& Leopold, 1929) or Hodgkin's disease (Skworzoff, 1930; Skworzoff \& Kazantzeva, 1930). The association of chronic myeloid leukaemia with malignant lymphoma, however, remains rarely recorded; the complicating disease process has been reticulosarcoma (Hanns, Israel \& Sacrez, 1934 ; Wilcken, 1957 ; Belotipetskaya \& Gets, 1960, lymphosarcoma (Yang, 1936; Forkner, 1938 ; Sardesai \& Bhatia, 1959 ; Howell \& Whitfield, 1963 ; Kurai \& Papp, 1965 ; Wilson \& van Slyck, 1966) and Hodgkin's disease (Samwick, Cohn \& Swiller, 1955; Lacker \& Sussman, 1963); Hodgkin's disease may also be

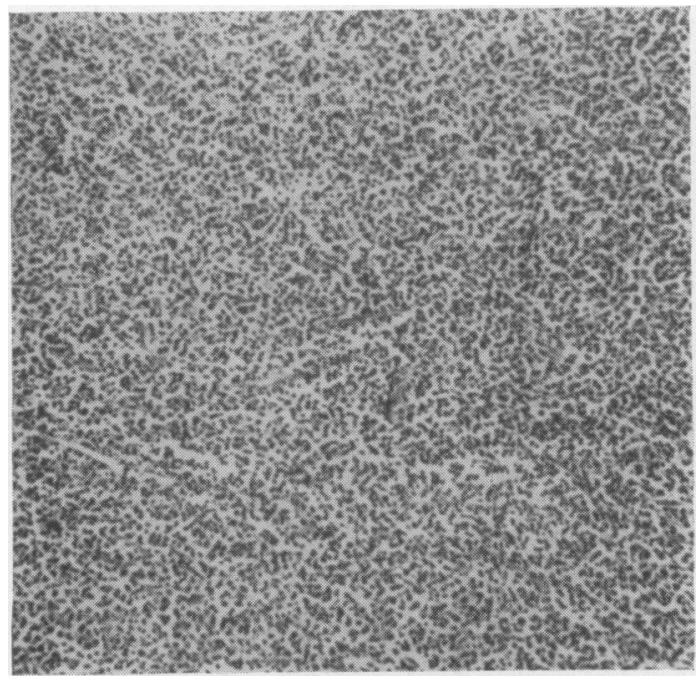

FIG. 3. Lymph-node section showing complete replacement of architecture with lymphoid cells. (Haematoxylin and eosin, $\times 80)$. 


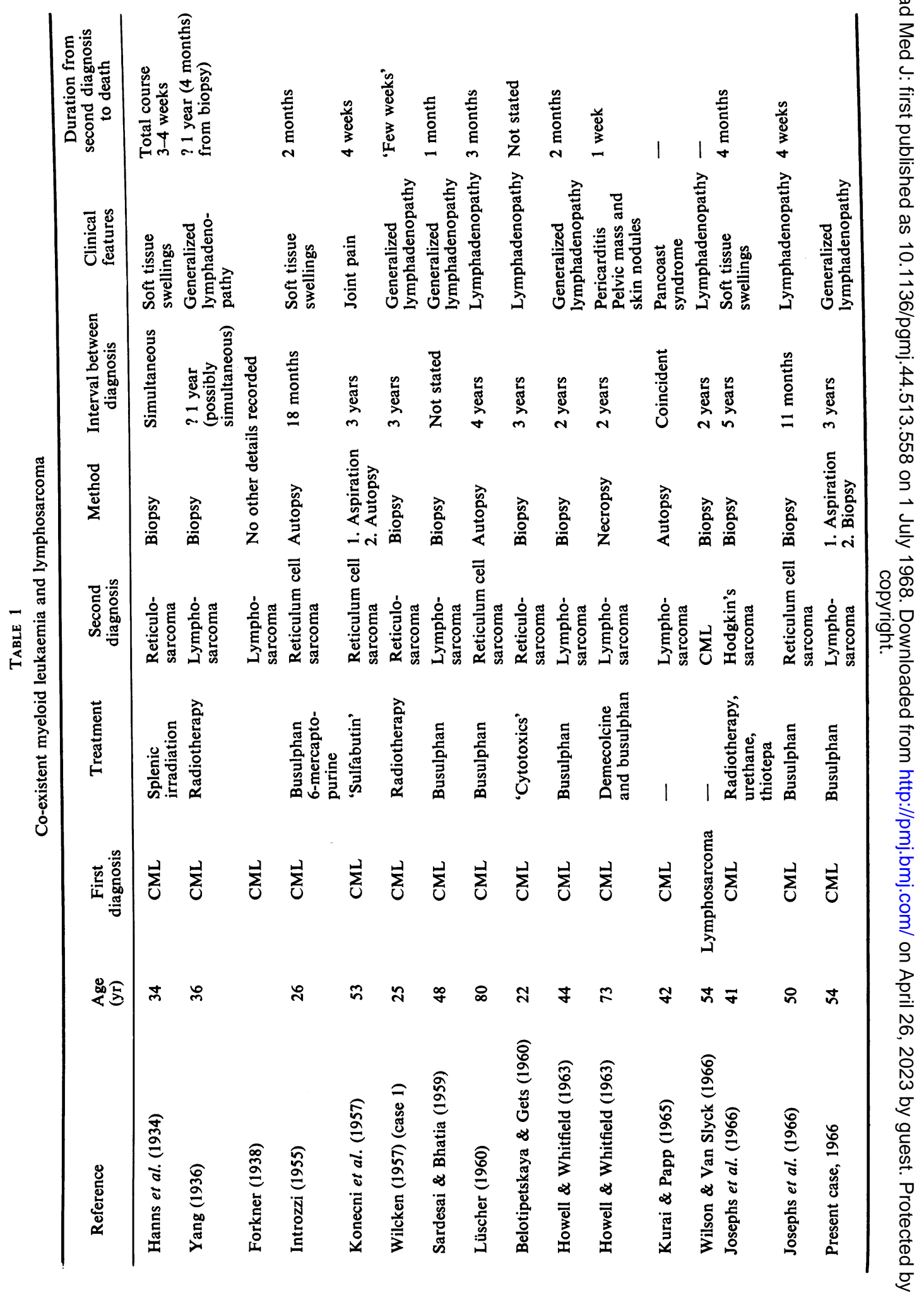


complicated by monocytic leukaemia (Craven, 1936). Usually the diagnosis of chronic myeloid leukaemia has been established prior to recognition of the complicating disease, but in the case of Wilson \& Van Slyck, a 54-year-old man, lymphosarcoma occurred 2 years before chronic myeloid leukaemia was detected (see Table 1).

Clinically the development of the second disease usually has been detected by lymphadenopathy-which occurred in the present casealthough soft tissue masses also occurred in some of the cases referred to. Lymphadenopathy, however, is a typical finding in the terminal illness of chronic myeloid leukaemia when it may be sudden and accompanied by fever and splenomegaly (Morrow et al., 1965). The peripheral blood does not always show the characteristics of acute leukaemia at this time, although this is the usual finding. Lymphadenopathy in chronic myeloid leukaemia is said to be rare (Dameshek \& Gunz, 1964) but that it may occur, and that it may indicate a different disease process, is noted by Hayhoe (1960). When lymphadenopathy is found a rapidly progressive course of the leukaemic process has been anticipated (Emile-Weil \& Isch-Wall, 1930 ; Scott, 1957). Clearly it is impossible to differentiate clinically the onset of the terminal phase of chronic myeloid leukaemia from the development of a complicating malignant lymphoma and some form of microscopic examination of the enlarged nodes is indicated. In the present case, as in that of Konecni, Andrejevnic \& Stosic (1957), needle aspirates yielded cytologically diagnostic material, which was later confirmed by routine histological methods. At necropsy the findings were those of chronic myeloid leukaemia only-the cervical nodes having been shrunken by radiotherapy. The diagnosis of two disorders of this type presents some difficulties; lymph nodes showing apparently typical changes of reticulum cell sarcoma may yield $\mathrm{Ph}_{1}$ positive cells (Carbone, 1966) and extramedullary tumours which resemble reticulum cell sarcoma may occur in states of myeloid metaplasia (Lieberman, Rosvall \& Ley, 1965). In some cases the progression has shown cytological features of 'la remontée cellulaire evolutif' described by Bessis (e.g. Introzzi, 1955 ; Konecni et al., 1957).

Both radiotherapy and alkylating agents are cytotoxic, mutagenic and carcinogenic, and it may be significant that all recorded cases had received one or other (sometimes mixed) forms of treatment. It has been postulated that myeloid proliferation might be partially controlled in these cases and any stimulus to abnormal proliferation therefore allowed to act more effectively on lymphoid tissues (Howell \& Whitfield, 1963). Such a sequence of events could be interpreted as support for the lymphoid origin of myeloid cells suggested by Maximow \& Bloom (1948) ; this view also has the support of Yoffey et al. (1961) although disputed by Ham (1961). The coexistence of lymphosarcoma, myeloid leukaemia and myeloma in a 70-year-old man might be regarded similarly (Hollard et al. 1965). That two previous cases were reported from this centre suggests that this event may not be very rare, and indicates the need for critical assessment of lymphadenopathy arising in the course of chronic myeloid leukaemia.

When 'lymphoma' complicates chronic myeloid leukaemia the leukaemia usually has been of the Philadelphia-negative type (Wilson \& Van Slyck, 1966). Repeated attempts in the present case failed to produce satisfactory metaphase plates and we therefore cannot comment on this particular aspect of the problem from personal experience.

In some cases of chronic myeloid leukaemia it has not been possible to demonstrate the Philadelphia abnormality (Tjio et al., 1966) and such patients appear to have a relatively poor prognosis; there has also been a high incidence of prior radiotherapy in such cases (Tough et al., 1962. It would seem useful to report the findings in all cases where lymphoma develops as the numbers are presently too small to allow any conclusions to be drawn concerning the role of the Philadelphia chromosome in this situation.

The interesting findings of Josephs, Zarafonetis $\&$ Durant (1966) in their case 2 (two cell lines, $46\left(\mathrm{Ph}_{1}+\right)$ and $52\left(\mathrm{Ph}_{1}+\right)$ with extra chromosomes in groups $\mathrm{C}$ and $\mathrm{D})$ clearly needs further study. The occurrence of extra chromosomes of either $\mathrm{Ph}_{1}$ type or group $\mathrm{C}$ type is well recognized but extra chromosomes in group $D$ are a new finding and have not been seen so far as we are aware in direct cultures from malignant reticuloses.

The final consideration is whether such cases are to be regarded in any other way than examples of coincidence. The increasing numbers of observations suggest that this may not be the correct view but until much larger numbers are available for analysis it is not possible to arrive at any firm conclusion.

\section{References}

Belotipetskaya, T.A. \& GeTS, I.I. (1960) Transformation of chronic myeloid leukaemia into reticulo-sarcomatosis. Arkh. Patol 22, 61. (Abstr. Soviet Med. 5, 241 (1961).) 
Beutler, E. (1954) The development of acute myelogenous leukaemia in a patient with reticulum cell lymphoma. $A n n$. intern. Med. 40, 1217.

Carbone, P. (1966) Cited by Josephs et al. (1966).

Craven, I.F. (1936) Clinical manifestations and treatment of leukaemia. Amer. J. Cancer, 26, 124.

DamesheK, W. \& Gunz, F. (1964) Leukaemia, 2nd edn, p. 224. Grune \& Stratton, New York.

FlashmaN, D.H. \& LeOPOLD, S.S. (1929) Leukosarcoma with report of a case beginning with primary retroperitoneal lymphosarcoma and terminating with leukaemia. Amer. J. med. Sci. 177, 651.

FORKNER, C.E. (1938) Leukaemia and Allied Disorders, p. 127. Macmillan, New York.

Emile-Weil, P. \& Isch-Wall, P. (1930) Le syndrome spléno-adénique dans la leucémie myeloide. Bull. Soc. Méd. Paris, 54, 757.

HaM, A.W. (1961) Histology, 4th edn, p. 188. Pitman, London.

Hanns, A., Israel, L. \& Sacrez, R. (1934) Sarcome lymphoblastique avec image sanguine de leucémie myéloide. Strasbourg méd. 94, 42. (Abstract in Amer. J. Cancer (1934), 21, 968.)

HAYHOE, F.G.J. (1960) Leukaemia, p. 243. Churchill, London.

Hollard, D., Muller, J.M., Leger, J. \& Denis, B. (1965) Association myélome, leucose myéloide, et lymphosarcome Lyon méd. 213, 967.

Howell, J.S. \& Whitfield, A.G.W. (1963) Chronic myeloid leukaemia with lymphosarcoma. J. clin. Path. 16, 432.

INTROzZI, P. (1955) Sur un cas de myélose leucémique chronique à évolution en réticulosarcomatose. Schweiz. med. Wschr. 85, 945.

Josephs, R.R., ZaRafonetis, F.J.D. \& DURANT, J.R. (1966) 'Lymphoma' in chronic granulocytic leukaemia. Amer. $J$. med. Sci. 251, 417.

KoneCnl, J., Andrejevnic, M. \& Stosic, Z. (1957) Evolution sarcomateuse d'une leucose myéloide chronique. Sang, 28, 660.

Kurai, J. \& PAPP, J. (1965) Pancoast-Syndrom bei simultanem Bestehen von Lymphosarkom und myeloider Leukose. Radiologica Austriaca, 15, 75.

LACKeR, M.J. \& Sussman, J.N. (1963) Leukaemia and Hodgkin's disease. Ann. intern. Med. 59, 369.

Lieberman, P.H., Rosvall, R.V. \& Ley, A.B. (1965) Extramedullary myeloid tumours in primary myelosclerosis. Cancer, 18, 727.
LÜSCHER, M. (1960) Reticulosarkom des humerus mit Spontanfraktur bei chromiscje myeloischer Leukämie. Schweiz. med. Wschr. 90, 893.

Maximow, A.H. \& Bloom, W. (1948) Texbook of Histology, 5th edn, p. 107. Saunders, Philadelphia.

Morrow, G.W., Pease, G.L., Stroebel, C.F. \& Bennett, W.A. (1965) Terminal phase of chronic myelogenous leukaemia. Cancer, 18, 369.

Samwick, A.A., Cohn, H. \& Swiller, A.I. (1955) Coexistent myelogenous leukaemia and Hodgkin's disease. Ann. intern. Med. 43, 868.

SARDESAI, H.V. \& BHATIA, K.C. (1959) Lymphosarcoma with myeloid leukaemia-case report. Indian J. mea. Sci. 13, 849.

Scotr, R.B. (1967) 'Leukaemia'-chronic myeloid leukaemia. Lancet, i, 1099.

Skworzoff, M.A. (1930) Acute myeloblastic leukaemia and Hodgkin's disease. Frankfurt. Z. Path. 40, 81.

Skworzoff, M.A. \& Kazantzeva, M.N. (1930) Case of lymphogranulomatosis with acute myelitic leukaemia. Klin. Med. 1, 1268.

STERnBerG, C. (1916) Leukosarcomatose und myeloblasten Leukamie. Beitr. Path. Anat. 61, 75.

Tuo, J.H., Carbone, PP., Whang, J. \& Frei, E. (1966) The Philadelphia chromosome and chronic myelogenous leukaemia. J. nat. Cancer Inst. 36, 567.

Tough, I.M., Court-Brown, W.M., Baikie, A.G., Buckton, K.E., Harnden, D.G., Jacobs, P.A. \& William, J.A. (1962) Chronic myeloid leukaemia; cytogenetic studies before and after splenic irradiation. Lancet, ii, 115.

WiLCKEN, D.E.L. (1957) A case of myeloid reticulosis. Med. J. Aust. i, 204.

Wilson, B.D. \& VAN SLYCK, E.J. (1966) Co-existent lym? phosarcoma and chronic granulocytic leukaemia. Cancer 19, 809.

YANG, C.S. (1934) Chronic myelogenous leukaemia in association with lymphosarcomatosis and transient diabetes insipidus. Chin. med. J. 50, 1153.

Yoffey, J.M., Thomas, D.B., Moffatt, D.J., Sutherland, I.H. \& Rosse, C. (1961) Biological Activity of the Leukocyte. Ciba Foundation Study Group No. 10, p. 45. Churchill, London.

ZefFReN, J.L. \& UltmanN, J.E. (1960) Reticulum cell sarcoma terminating in acute leukaemia. Blood, 15, 277. 